Proceedings

\title{
Milk Microbiota: A Source of Antimicrobial-Producing Bacteria with Potential Application in Food Safety ${ }^{\dagger}$
}

\author{
Alexandre Lamas *, Laura Sanjulián, Alberto Cepeda, Cristina Fente and Patricia Regal
}

Citation: Lamas, A.; Sanjulián, L.; Cepeda, A.; Fente, C.; Regal, P. Milk Microbiota: A Source of AntimicrobialProducing Bacteria with Potential Application in Food Safety.

Proceedings 2021, 70, 11. https://doi.org/ 10.3390/foods_2020-07720

Published: 10 November 2020

Publisher's Note: MDPI stays neutral with regard to jurisdictional claims in published maps and institutional affiliations.

\section{(1)}

Copyright: () 2021 by the authors. Licensee MDPI, Basel, Switzerland. This article is an open access article distributed under the terms and conditions of the Creative Commons Attribution (CC BY) license (http://creativecommons.org/licenses/by/4.0/).

\author{
Laboratorio de Higiene Inspección y Control de Alimentos, Departamento de Química Analítica, \\ Nutrición y, Bromatología, Universidad de Santiago de Compostela, 27002 Lugo, Spain; \\ laura.sanjulian.fernandez@usc.es (L.S.); alberto.cepeda@usc.es (A.C.); cristina.fente@usc.es (C.F.); \\ patricia.regal@usc.es (P.R.) \\ * Correspondence: alexandre.lamas@usc.es; Tel.: +34-982822455 \\ + Presented at the 1st International Electronic Conference on Food Science and Functional Foods, \\ 10-25 November 2020; Available online: https://foods_2020.sciforum.net/.
}

\begin{abstract}
Antimicrobial and biocide resistance is a major public health problem today. Therefore, one of the main scientific challenges nowadays is the search for alternatives to these substances. One of these potential alternatives are the bacteriocins. Microbiota are a potential source of bacteriocinproducing bacteria that need to be studied. In this study, a total of 40 samples of human milk and 10 samples of cow milk were collected from healthy individuals and stored at $-20{ }^{\circ} \mathrm{C}$ until use. Colonies isolated from these samples that showed antimicrobial activity against Lactobacillus delbrueckii ssp. bulgaricus in the overlaid assays were selected. Well diffusion assays were carried out with the cell-free supernatant (CFS) from these colonies neutralized to $\mathrm{pH}$ and inhibition zones were recorded. The activity against eight common bacterial pathogens was evaluated. A total of 32 colonies with potential antimicrobial activity were isolated. The neutralized CFS of 10 strains showed antimicrobial activity against at least one pathogen tested in the well diffusion assays. Eight of the 10 CFS inhibited the growth of Staphylococcus aureus. These CFS also showed activity against Staphylococcus epidermidis, Streptococcus agalactiae, Pseudomonas aeruginosa , L. monocytogenes, Clostridium perfringens and Clostridioides difficile. The next steps of the research will be $16 \mathrm{~s}$ rRNA sequencing to identify the species of isolates and mass spectrometry to determine the antimicrobial product produced by isolation. Finally, this study demonstrated that milk microbiota are a potential source of new producing bacteriocin bacteria that can be used in the formulation of new food products.
\end{abstract}

Keywords: milk; microbiota; antimicrobial potential; food safety; bacteriocin

\section{Introduction}

The discovery and use of antibiotics were a major advance in human health. Bacterial infections that could end in death began to be easily treated with these substances. Antibiotics also revolutionized animal production $[1,2]$. These substances are used to treat animal infections, but also were and still are used in some countries as growth promoters [3]. Indiscriminate use of antibiotics resulted in the spread of antimicrobial resistance. Thus, at present, there is a global problem due to the appearance of multi-resistance in pathogenic bacteria [4]. This has resulted in a significant increase in the number of deaths associated with multi-resistant bacteria. In the field of food science, there is also increasing concern among consumers about the use of synthetic preservatives in food, as some of them, such as sulfites and nitrites, have been linked to possible adverse effects on human health $[5,6]$. There has also been an increase in the resistance of food pathogens to biocides commonly used in the food industry [7]. Therefore, one of the main challenges of actual society is the search for alternative substances to antibiotics and preservatives. In the last years, microbiota from different sources have emerged as a potential source of natural substances with antimicrobial activity [8]. Many of the bacteria present in the microbiota 
synthesize bacteriocins, ribosomally produced antimicrobial peptides synthesized by both Gram-positive and Gram-negative bacteria with activity against closely related bacteria (narrow spectrum) or a diverse group of bacteria (broad spectrum) [9]. Although some bacteriocins such as nisin are already known, there is still a large number to be discovered and evaluated. The aim of this study was to isolate bacteria with antimicrobial activity from the microbiota of breast milk and cow milk.

\section{Material and Methods}

A total of 40 samples were included in this study for the isolation of strains with potential antimicrobial activity against different common pathogens. From these, 30 milk samples were collected aseptically from healthy women at different breastfeeding stages. The other 10 samples were collected individually from different dairy cows. After collection, samples were kept at $-20^{\circ} \mathrm{C}$ until use.

The isolation of strains with potential antimicrobial activity was carried out using an overlaid method with Lactobacillus delbrueckii ssp. bulgaricus. Briefly, a volume of $1 \mathrm{~mL}$ of milk was serially diluted in maximum recovery diluent (MRD) $(0.85 \% \mathrm{NaCL}$ and $0.01 \%$ Tryptone) until a final dilution of $10^{-4}$. A volume of $100 \mu \mathrm{L}$ of the initial sample and dilutions were then spread in different plate agar media. The agar media included in this study were Brain heart infusion (BHI)(Merck Millipore, Darmstadt, Germany) agar and Columbia agar (Merck Millipore). The BHI plates were incubated at $37^{\circ} \mathrm{C}$ for $48 \mathrm{~h}$ aerobically and Columbia agar plates were incubated $72 \mathrm{~h}$ at $37^{\circ} \mathrm{C}$ anaerobically using GENbox atmosphere generators (bioMérieux, Craponne, France) and anaerobic jars. After incubation, plates that showed separated colonies were overlaid with Man Rogosa Sharpe (MRS)(Merck Millipore) containing $0.75 \%$ agar seeded with $0.25 \%$ of an overnight culture of Lactobacillus delbrueckii ssp. bulgaricus LMG 6901 in MRS broth. The plates were then incubated anaerobically for 24 $\mathrm{h}$ at $37^{\circ} \mathrm{C}$. After incubation, the colonies that showed inhibition zones of the indicator $L$. delbrueckii ssp. bulgaricus LMG 6901 were picked and streaked in BHI agar and incubated for $24 \mathrm{~h}$ at $37^{\circ} \mathrm{C}$ to obtain pure colonies. Finally, a pure colony was picked and transferred to BHI broth and incubated $24 \mathrm{~h}$ at $37^{\circ} \mathrm{C}$. Each strain was stocked in $20 \%$ glycerol and stored at $-20^{\circ} \mathrm{C}$ for further characterization.

The characterization of the antimicrobial activity of the strains was determined using the well diffusion assay (WDA). Briefly, milk isolated strains were grown in $50 \mathrm{~mL}$ polystyrene filled with $20 \mathrm{~mL}$ of $\mathrm{BHI}$ medium for $48 \mathrm{~h}$ at $37^{\circ} \mathrm{C}$. After incubation, the growth media were centrifuged at $5000 \times g$ for $15 \mathrm{~min}$. The cell free supernatant (CFS) was collected and filtered using $0.22 \mu \mathrm{m}$ syringe filters and saved at $-20^{\circ} \mathrm{C}$ until use. To eliminate inhibition due to acids produced during bacterial growth, the $\mathrm{pH}$ of the $\mathrm{CFS}$ was determined and neutralized to $\mathrm{pH}$ 7.0-7.2 using $2 \mathrm{M} \mathrm{NaOH}$. The antimicrobial activity of CFS was determined against 8 different indicator bacteria (Staphylococcus epidermidis CECT 59, Staphylococcus aureus CECT 231, Salmonella typhimurium CECT 4594, Streptococcus agalactiae CECT 183T, Pseudomonas aeruginosa CECT 108, Listeria monocytogenes CECT 934, Clostridium perfringens CECT $376 \mathrm{~T}$ and Clostridioides difficile CECT 531T). These strains were grown in BHI for $24 \mathrm{~h}$ at 37 ${ }^{\circ} \mathrm{C}$ aerobically, with the exception of $C$. difficile CECT 531T and C. perfringens CECT 376T, which were grown anaerobically in Reinforced Clostridial Medium (RCM)(VWR, Spain) or $24 \mathrm{~h}$ at $37^{\circ} \mathrm{C}$. BHI media with $0.75 \%$ agar was seeded with $0.25 \%$ of indicator bacteria and $20 \mathrm{~mL}$ were transferred to agar plates. For $C$. difficile CECT 531T and C. perfringens CECT 376T, RCM was used instead of BHI. After the agar solidified, $5 \mathrm{~mm}$ diameter holes were made and filled with $75 \mu \mathrm{L}$ of the milk isolated strain WDAs. The plates were incubated for $24 \mathrm{~h}$ at $37^{\circ} \mathrm{C}$ and the inhibition zones were measured.

\section{Results}

A total of 32 colonies with potential antimicrobial activity according the overlaid result with L. delbrueckii ssp. bulgaricus LMG 6901 were isolated. From these, 28 colonies 
were isolated from breast milk and four colonies were isolated from cow milk. The neutralized CFS of 10 strains showed antimicrobial activity against at least one pathogen tested in the well diffusion assays. Seven strains were isolated from breast milk and three strains were isolated from cow milk. Eight of the 10 CFS inhibited the growth of S. aureus. These CFS also showed activity against S. epidermidis, S. agalactiae, P. aeruginosa, L. monocytogenes, and $C$. perfringens and one strain against $C$. difficile (Figure 1).

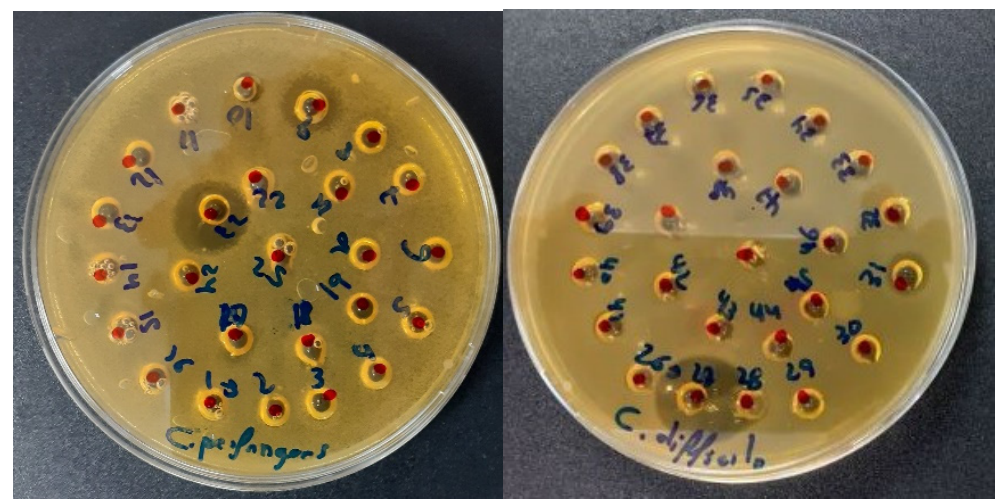

Figure 1. Well diffusion assays of Clostridium perfringens and Clostridioides difficile with two strains isolated from milk showing antimicrobial activity.

The inhibition potential of each strain was calculated as the area of the zone $\pi r^{2}-$ the area of the well $\pi \mathrm{r}^{2}$ in millimeters (Table 1). Although 8 of the 10 strains isolated inhibited the growth of Staphylococcus aureus, only two strains showed strong inhibition.

Table 1. Spectrum of inhibition of bacteriocin-producing milk isolates against indicator strains according to well diffusion assays. -, no inhibition; +, $<50 \mathrm{~mm}^{2} ;++, 50-150 \mathrm{~mm}^{2}$; +++, 150-249 $\mathrm{mm}^{2}$; ++++, 150-249 $\mathrm{mm}^{2}$.

\begin{tabular}{|c|c|c|c|c|c|c|c|c|c|c|}
\hline Indicator/Strain & LM18.1 & LM16.1 & LM61 & LM95 & LM27 & LM12 & LM88 & L3.1 & L3.2 & L6.10 \\
\hline Staphylococcus epidermidis CECT 59 & - & - & - & + & - & & & - & & \\
\hline Staphylococcus aureus CECT 231 & - & - & + & + & + & +++ & + & ++++ & + & + \\
\hline Streptococcus agalactiae CECT $183 \mathrm{~T}$ & + & ++ & ++++ & & & & +++ & - & - & - \\
\hline Clostridium perfringens CECT $376 \mathrm{~T}$ & - & - & + & - & - & - & - & - & - & - \\
\hline Clostridioides difficile CECT 531T & ++ & +++ & - & - & - & - & - & - & +++ & ++++ \\
\hline
\end{tabular}

It is also interesting that four of the seven strains isolated from breast milk inhibited the growth of Streptococcus agalactiae CECT 183T. Especially, LM61 showed strong inhibition activity. Two strains of breast milk and two strains of cow milk also inhibited the growth of Clostridioides difficile CECT 531T, and L6.10 showed strong inhibition activity. Breast milk and cow milk microbiota are a source of antimicrobial-producing bacteria. In the next steps of the work, the strains isolated from breast milk and cow milk will be identified by 16s rRNA sequencing and mass spectrometry will be used to determine the antimicrobial product produced by isolation.

Author Contributions: Conceptualization, A.L. and P.R.; methodology, A.L. and L.S.; software, L.S.; formal analysis, A.L. and P.R.; investigation, A.L. and L.S.; resources, C.F.; data curation, A.L. and P.R.; writing - original draft preparation, A.L. and P.R.; writing-review and editing, C.F. and A.C.; visualization, L.S.; supervision, A.C.; project administration, P.R. and C.F. All authors have read and agreed to the published version of the manuscript.

Funding: This research received no external funding. 
Institutional Review Board Statement: Galician Clinical Research Ethics Committee (Approval code 2016/280). Approved in 2016.

Informed Consent Statement: All subjects gave their informed consent for inclusion before they participated in the study. The study was conducted in accordance with the Declaration of Helsinki, and the protocol was approved by Galician Clinical Research Ethics Committee (Approval code 2016/280).

Data Availability Statement: Samples and strains are available from authors upon request.

Acknowledgments: Alexandre Lamas has a postdoctoral fellowship from Xunta de Galicia (Axudas de apoio á etapa de formación posdoutoral IN606B (Modalidade A)).

Conflicts of Interest: The authors declare no conflict of interest.

\section{References}

1. Davies, J.; Davies, D. Origins and evolution of antibiotic resistance. Microbiol. Mol. Biol. Rev. 2010, 74, 417-433.

2. Mathew, A.G.; Cissell, R.; Liamthong, S. Antibiotic resistance in bacteria associated with food animals: A United States perspective of livestock production. Foodborne Pathog. Dis. 2007, 4, 115-133.

3. Graham, J.P.; Boland, J.J.; Silbergeld, E. Growth promoting antibiotics in food animal production: An economic analysis. Public Health Rep. 2007, 122, 79-87.

4. Wallace, M.J.; Fishbein, S.; Dantas, G. Antimicrobial resistance in enteric bacteria: Current state and next-generation solutions. Gut Microbes 2020, 12, 1799654.

5. Weitzberg, E.; Lundberg, J.O. Novel aspects of dietary nitrate and human health. Annu. Rev. Nutr. 2013, 33, 129-159.

6. Vally, H.; Misso, N.L.; Madan, V. Clinical effects of sulphite additives. Clin. Exp. Allergy 2009, 39, $1643-1651$.

7. Drauch, V.; Ibesich, C.; Vogl, C.; Hess, M.; Hess, C. In vitro testing of bacteriostatic and bactericidal efficacy of commercial disinfectants against Salmonella Infantis reveals substantial differences between products and bacterial strains. Int. J. Food Microbiol. 2020, 328, 108660.

8. Durand, G.A.; Raoult, D.; Dubourg, G. Antibiotic discovery: History, methods and perspectives. Int. J. Antimicrob. Agents 2019, 53, 371-382.

9. Mills, S.; Ross, R.P.; Hill, C. Bacteriocins and bacteriophage; a narrow-minded approach to food and gut microbiology. FEMS Microbiol. Rev. 2017, 41, S129-S153. 